\title{
Comment on "Hydrochemical studies of Cross River Basin (southeastern Nigeria) river systems using cross plots, statistics and water quality index" published in Environ. Earth Sci. (2013) 70:3043-3056
}

\author{
Moslem Sharifinia ${ }^{1}$
}

Received: 17 December 2015/ Accepted: 25 February 2016/Published online: 11 April 2016

(C) Springer-Verlag Berlin Heidelberg 2016

Please allow me to humbly comment on an attentiongrabbing paper published by Edet et al. (2013) based on major point below.

The original article has been published inadvertently with some errors in Table 2. The corrected Table 2 is given below and errors specified with red font. According this error, results of WQI calculation are wrong and require complete revision. Lastly, this is not my intention to offend the authors of the published paper but just my honest comments in a constructive way as an old saying goes 'Nothing is perfect'.

Table 2 Standards and weights used in the study

\begin{tabular}{lllll}
\hline Parameter & $\begin{array}{l}\text { WHO } \\
(1984, \\
1993)\end{array}$ & $\begin{array}{l}\text { World average } \\
\text { (Turekian 1977) }\end{array}$ & $\begin{array}{l}\text { Assigned } \\
\text { weight }\end{array}$ & $\begin{array}{l}\text { Relative } \\
\text { weight }\end{array}$ \\
\hline $\mathrm{TDS}$ & 1000 & - & 3 & 0.11 \\
$\mathrm{pH}$ & 7.5 & - & 4 & 0.14 \\
$\mathrm{Hardness}$ & 75 & & 2 & 0.07 \\
$\mathrm{Na}$ & 200 & 5.20 & 1 & 0.04 \\
$\mathrm{~K}$ & 12 & 1.30 & 1 & 0.04 \\
$\mathrm{Ca}$ & 100 & 13.40 & 2 & 0.07 \\
$\mathrm{Mg}$ & 30 & 3.40 & 1 & 0.04 \\
$\mathrm{Cl}$ & 250 & 5.80 & 5 & 0.18 \\
$\mathrm{NO}_{3}$ & 50 & & 4 & 0.14 \\
$\mathrm{SO}_{4}$ & 250 & 8.30 & 3 & 0.11 \\
$\mathrm{HCO}_{3}$ & - & 52.00 & 2 & 0.07 \\
$\mathrm{Total}^{2}$ & & & 28 & 1 \\
\hline
\end{tabular}

Moslem Sharifinia

moslem.sharifinia@yahoo.com

1 Department of Marine Biology, Collage of Sciences, Hormozgan University, Minab Road, Bandar Abbas, Iran

\section{References}

Turekian K (1977) Geochemical distribution of elements. Encyclopedia of science and technology 4:627-630

World Health Organization (WHO) (1984) Guidelines for drinking water quality, 2nd edn. WHO, Geneva

World Health Organization (WHO) (1993) Guidelines for drinking water quality: health criteria and other supporting information, 2nd edn. WHO, Geneva 